\title{
The number of granular cells in a cerebellar neuronal network model engaged during robot control increases with the complexity of the motor task
}

\author{
Ruben-Dario Pinzon-Morales, Yutaka Hirata* \\ From The Twenty Third Annual Computational Neuroscience Meeting: CNS*2014 \\ Québec City, Canada. 26-31 July 2014
}

\section{Introduction}

The granular cells $(\mathrm{Gr})$ in the cerebellum have been proposed to perform adaptive spatio-temporal coding [1] to relay rich information to the Purkinje cell, and thus they are critical for the proper operation of the cerebellum [2]. Elimination of all $\mathrm{Gr}$ cells induced behavioral symptoms such as ataxia and hypotonia [3]. Partially silencing Gr cells showed that the overall motor performance was minimally affected whereas demanding tasks or memory consolidation processes were compromised [4]. Here we use a physio-anatomically inspired cerebellar neuronal network (CNN) to study the role of the Gr cells during control of an unstable two-wheel balancing robot [5].

\section{Methods}

The CNN comprises 755 Gr, 5 Golgi (Go), 15 basket/ stellate $(\mathrm{Ba} / \mathrm{St})$, and 1 Purkinje $(\mathrm{Pk})$ cells. Inputs to the $\mathrm{CNN}$ carried by mossy fibers (mfs) provided the desired motion trajectories of the robot. Inhibitory feedback loop between Gr and Go, and feed-forward inhibitory loop between $\mathrm{Ba} / \mathrm{St}$ and $\mathrm{Pk}$ were included as in the real cerebellum. A proportional and differential (PD) controller sharing the same mfs inputs was introduced to represent the non-cerebellar input to the vestibular nucleus $(\mathrm{Vn})$. The Vn computed the arithmetic difference between the PD and the Pk output and produced the motor command to drive the robot. The error signal to the Pk cell is conveyed by the climber fiber (cf). Bidirectional plasticity at Gr-Pk synapses (LTP/LTD) induced by the $\mathrm{cf}$ was implemented as a basis for motor

\footnotetext{
* Correspondence: yutaka@isc.chubu.ac.jp

Department of Computer Science, Chubu University Graduate School of Engineering, Kasugai, 487-8501, Japan
}

learning [6]. The desired motion of the wheel angle position of the robot was sinusoidal waves or a band limited random noise (BLRN) while that of the body tilt angle was zero. The complexity of the control task changed from simple to difficult as the frequency of the sinusoidal wave changed form $0.1 \mathrm{~Hz}$ to $0.4 \mathrm{~Hz}$, and very difficult when the BLRN (cutoff frequencies $0.2 \mathrm{~Hz}$ and $0.5 \mathrm{~Hz}$ ) desired motion was used. The sinusoidal desired motion was given for 100 cycles and the BLRN for $10 \mathrm{~s}$. At the end of the experiment the Gr-Pk synapweights were sorted to identify the number of cells

\section{Results}

It was found that less than half of the Gr cells in the $\mathrm{CNN}$ were required to form $90 \%$ of the Pk output for all the desired motion employed. Interestingly, as the complexity of the motor task increased, the number of Gr cells required also increased. Knocking down the output of the most contributing $100 \mathrm{Gr}$ cells showed that the motor performance was momentarily affected, but the $\mathrm{CNN}$ was able to re-adjust the other $\mathrm{Gr}-\mathrm{Pk}$ synaptic weights and recover the motor performance. These results are in line with other computational mod, such as [7] that predicted that motor performance Gr cells.

\section{Conclusions}

In our robot control framework, the number of Gr cells driving the Pk cell output increased with the complexity of the motor task. Sparse coding in the Gr layer 
permitted the engagement of $\mathrm{Gr}$ cells to foster the motor performance.

Published: 21 July 2014

\section{References}

1. Solinas $S$, et al: A realistic large-scale model of the cerebellum granular layer predicts circuit spatio-temporal filtering properties. Front Cell Neurosci 2012, 4(12).

2. D'Angelo E: Rebuilding cerebellar network computations from cellular neurophysiology. Front Cell Neurosc 2010, 4(131).

3. Kim JC, et al: Linking genetically defined neurons to behavior through a broadly applicable silencing allele. Neuron 2009, 63(3):305-15.

4. Galliano $E$, et al: Silencing the majority of cerebellar granule cells uncovers their essential role in motor learning and consolidation. Cell Rep 2013, 3(4):1239-51.

5. Pinzon-Morales R-D, et al: Error signals used for cerebellar motor learning: evaluation in real world adaptive robot control using a cerebellar neuronal network model. J Neural Eng, (in review).

6. Ito M: Cerebellar circuitry as a neuronal machine. Prog Neurobiol 2006, 78(3-5):272-303

7. Schweighofer $\mathrm{N}$, et al: Unsupervised learning of granule cell sparse codes enhances cerebellar adaptive control. Neuroscience 2001, 103(1):35-50.

doi:10.1186/1471-2202-15-S1-P143

Cite this article as: Pinzon-Morales and Hirata: The number of granular cells in a cerebellar neuronal network model engaged during robot control increases with the complexity of the motor task. BMC

Neuroscience 2014 15(Suppl 1):P143.

\section{Submit your next manuscript to BioMed Central} and take full advantage of:

- Convenient online submission

- Thorough peer review

- No space constraints or color figure charges

- Immediate publication on acceptance

- Inclusion in PubMed, CAS, Scopus and Google Scholar

- Research which is freely available for redistribution

Submit your manuscript at www.biomedcentral.com/submit
C Biomed Central 